\title{
Galectin-1 Inhibitor OTX008
}

National Cancer Institute

\section{Source}

National Cancer Institute. Galectin-1 Inhibitor OTX008. NCI Thesaurus. Code C103828.

A calixarene-based compound and galectin-1 (Gal-1) inhibitor with potential antiangiogenic and antineoplastic activities. Upon subcutaneous administration, galectin-1 inhibitor OT X008 binds Gal-1 which leads to Gal-1 oxidation and proteasomal degradation, through an as of yet not fully elucidated mechanism, and eventually downregulation of Gal-1. This decreases tumor cell growth and inhibits ang iogenesis. Gal-1, a multifunctional carbohydrate-binding protein, is often overexpressed on tumor cells and plays a key role in cancer cell proliferation, apoptosis, tumor angiogenesis and evasion of immune responses. 